4

\title{
SUBCRITICAL WATER EXTRACTION AND CHARACTERIZATION OF BIOACTIVE COMPOUNDS FROM HAEMATOCOCCUS PLUVIALIS MICROALGA
}

\author{
I. Rodríguez-Meizoso ${ }^{1}$, L. Jaime ${ }^{2}$, S. Santoyo ${ }^{2}$, F.J. Señoráns ${ }^{2}$, A. Cifuentes ${ }^{1}$, E. Ibáñez ${ }^{1}$
} (1)

${ }^{1}$ Instituto de Fermentaciones Industriales, CSIC, Juan de la Cierva 3, 28006 Madrid, Spain.

${ }^{2}$ Sección Dept. de Ciencias de la Alimentación, Universidad Autónoma de Madrid, Campus de Cantoblanco, 28049 Madrid, Spain.

\section{KEY WORDS}

Haematococcus pluvialis, microalgae, subcritical water extraction, bioactive compounds, antioxidants, antimicrobials, chemical characterization.

\section{ABSTRACT}

In this work, extraction and characterization of compounds with antioxidant and antimicrobial activity from Haematococcus pluvialis microalga in red phase have been carried out. To do this, subcritical water extraction (SWE) has been combined with analytical techniques such as HPLC-DAD, HPLC-QqQMS and GC-MS and in-vitro assays (i.e., for antioxidant and antimicrobial activity). The effect of the extraction temperature (50, 100, 150 and $\left.200{ }^{\circ} \mathrm{C}\right)$ and solvent polarity has been studied in terms of yield and activity of the extracts. Results demonstrate that the extraction temperature has a positive influence in the extraction yield and antioxidant activity. Thus, the extraction yield achieved with this process was higher than $30 \%$ of dry weight at $200{ }^{\circ} \mathrm{C}$ as extraction temperature. Moreover, the extract obtained at 200 ${ }^{\circ} \mathrm{C}$ presented the highest antioxidant activity by far, while temperature does not seem to significatively affect the antimicrobial activity. Chemical composition was determined by HPLC-DAD, HPLC-QqQMS and GC-MS. Short chain fatty acids turned out to be responsible of the antimicrobial activity, whereas the antioxidant activity was correlated to vitamin $\mathrm{E}$ (present exclusively in the $200{ }^{\circ} \mathrm{C}$ extract), together with simple phenols, caramelization products and possible Maillard reaction products obtained during the extraction at high temperatures. 


\section{INTRODUCTION}

At present, one of the main interests in Food Science and Technology is the extraction and characterization of new functional ingredients of natural origin. These biological active ingredients can be used not only as natural preservatives against food degradation, but also can be added to food as a functional ingredient able to promote our health [1].

Algae are a very interesting natural source of new compounds such as antioxidants and antimicrobials [2]. In fact, some algae are organisms that live in complex habitats submitted to extreme conditions (for example, changes of salinity, temperature, nutrients, UV/VIS irradiation), therefore, they must adapt rapidly to the new environmental conditions to survive, producing a great variety of secondary (biologically active) metabolites, which cannot be found in other organisms [3]. Also, considering their great taxonomic diversity, investigations related to the search of new biologically active compounds from algae can be seen as an almost unlimited field.

Haematococcus pluvialis (chlorophyceae) is a fresh-water green unicellular alga that has already been studied due to its ability to accumulate under environmental stress astaxanthin, an orange-red carotenoid with strong antioxidant properties [4]. Moreover, as demonstrated for other algae and microalgae [5-8], along with astaxanthin, different compounds with antibacterial, antiviral and/or antifungical activity could be expected to be found also in this microalga. Therefore, Haematococcus pluvialis can be considered as a potential natural source of natural compounds that could be used as ingredients for preparing functional foods. At present, organic solvents in traditional extraction approaches $[9,10]$ or under pressurized liquid extraction (PLE) conditions [11] have been used to extract carotenoids from Haematococcus. However, in order to obtain natural ingredients for the food industry, it is clearly preferred to obtain extracts by using green technologies, avoiding the use of toxic solvents.

In this regard, subcritical water extraction (SWE) uses pressurized water at high temperatures to keep it in the liquid state, achieving safe, "green" and rapid extractions. Elevated temperatures modify the dielectric constant of the water resulting in the possibility of tuning its polarity, thus obtaining selective extractions, as have been shown for aromatic plants [12]. Thus, SWE can be a good choice to obtain extracts from Haematococcus pluvialis with functional activity and compatible with food regulations. In this sense, Haematococcus pluvialis cytoplasm is enclosed by a thick cyst-like cell wall. This protective barrier can hinder the extraction and bioavailability of bioactive compounds [13], so sample pretreatment is necessary in order to obtain good extraction yields. It is widely accepted that 
1 astaxanthin is biosynthesized up to $3 \%$ of concentration [11] and there are several reports on 2 the treatment of cells to enhance its extractability and bioavailability [14]. In the present work, we have also faced this problem combining SWE with procedures to break this cell wall. Scanning electron microscopy (SEM) of the residual sample has been carried out in order to study the influence of these processes in the cell wall damage.

The general goal of the present investigation was, therefore, to study the suitability of new green processes, mainly based on SWE, to obtain extracts with high yields from Hameatococcus pluvialis and evaluate their potential as antioxidant and antimicrobial agents. In order to produce an useful natural food additive it is necessary to characterize and identify the compounds that contribute to the biological activity of the extracts. In this sense, several methods have been used to tentatively identify the compounds responsible of such activities, such as HPLC-DAD, HPLC-QqQMS and GC-MS.

\section{EXPERIMENTAL}

\subsection{Samples and chemicals.}

Haematococcus pluvialis (BNA 10/024, National Bank of Algae, Canary Islands, Spain), were grown in modified Bold's Basal Medium [15] enriched with $\mathrm{NaNO}_{3}(0.75 \mathrm{~g} / \mathrm{l})$. Cells (green phase) were cultured photoutotrophycally in 201 Carboys bubbled with air, at 25 ${ }^{\circ} \mathrm{C}$, in light:dark cycles $(16: 8)$ with white fluorescent lamps $\left(80 \mu \mathrm{mol} \mathrm{m}{ }^{-2} \mathrm{~s}^{-1}\right)$. To induce astaxanthin biosynthesis (red phase) exponentially grown cultures were transferred to nitrogen deprived medium and continuously illuminated with $200 \mu \mathrm{mol} \mathrm{m} \mathrm{m}^{-2} \mathrm{~s}^{-1}$ during 6 days. Cells were collected by centrifugation, freeze dried and stored at inert atmosphere until extraction. Just before the extraction, the samples were freshly pretreated by freezing and mashing the microalgae with liquid nitrogen in a ceramic mortar. The process was repeated three times in order to induce cell-wall lyses.

The water used was from a Milli-Q filtration system (Millipore, Billerica, MA, USA) and it was deoxygenated in an ultrasound bath.

Different mixtures of standard lineal hydrocarbons from n-undecane to n-octacosane were from Sigma-Aldrich Chemie (Steinheim, Germany). Two derivatizing reagents (Ntrimethylsilylimidazole and chlorotrimethylsilane redistilled) were from Sigma (St. Louis, MO). The other derivatizing agent, pyridine dried, and potassium chloride were supplied by Merck (Darmstadt, Germany). Acetic acid HPLC grade was obtained from Scharlau Chemie S.A. (Barcelona, Spain). 


\subsection{Subcritical Water Extraction.}

Extractions of Haematococcus pluvialis were performed using an Accelerated Solvent Extractor (ASE 200, Dionex Corporation, Sunnyvale, CA, USA) equipped with a solvent controller unit. Extractions were performed at four different extraction temperatures (50, 100, 150 and $200^{\circ} \mathrm{C}$ ) and 20 minutes as extraction time. Previously, an extraction cell heat-up was carried out for a given time, that changed according to extraction temperature (the heat-up time is automatically fixed by the equipment, i.e., $5 \mathrm{~min}$ when the extraction temperature was 50 and $100^{\circ} \mathrm{C}, 7 \mathrm{~min}$ at $150^{\circ} \mathrm{C}$ and $9 \mathrm{~min}$ at $200^{\circ} \mathrm{C}$ ). All extractions were performed in $11 \mathrm{ml}$ extraction cells, containing $1.0 \mathrm{~g}$ of sample, and were carried out in duplicate.

The extraction procedure was as follows: (i) sample is loaded in the cell; (ii) cell is filled with solvent up to a pressure of 1500 psi, (iii) initial heat-up time is applied; (iv) a static extraction with all systems valves closed is performed; (v) the cell is rinsed (with $60 \%$ cell volume using extraction solvent); (vi) solvent is purged from the cell with $\mathrm{N}_{2}$ gas and (vii) depressurization takes place. Between extractions, a rinse of the complete system was made in order to overcome any extract carry over. To minimize the loss of volatiles and to avoid sample degradation, the extracts were quickly cooled down to freezing temperatures by placing the vials in a water-ice bath. The extracts were frozen in the $-20{ }^{\circ} \mathrm{C}$ freezer, and the water was removed by freeze drying.

\subsection{Treatment of the sample previous extraction.}

In order to obtain the highest possible extraction yields, different pre-treatments of the sample to tentatively break the cell wall were studied:

1. The sample (2 g) was suspended in water $(4 \mathrm{ml})$ and treated in an ultrasound bath for $5 \mathrm{~min}$.

2. The sample ( $2 \mathrm{~g}$ ) was suspended in water $(4 \mathrm{ml})$, followed by three freezingthawing cycles, carried out in a $-20{ }^{\circ} \mathrm{C}$ freezer. The slow freezing process favours the formation of big crystals that better damage the cell wall.

3. The sample (2 g) was suspended in water $(4 \mathrm{ml})$, followed by a homogenization using an Ultraturrax T-25 (I.C.T., La Rioja, Spain) dispersing tool at $11000 \mathrm{rpm}$ speed.

4. The sample ( $2 \mathrm{~g}$ ) was treated by three freezing-smashing-thawing cycles, carried out in a ceramic mortar, by a fast freezing with liquid $\mathrm{N}_{2}$ over the sample. 
In procedures 1, 2 and 3, the sample was centrifuged afterwards at $5200 \mathrm{rpm}$ for $5 \mathrm{~min}$ at $5{ }^{\circ} \mathrm{C}$ in a Haraeus Sepatech Biofuge 22R centrifuge (Hanaus, Germany). The supernatant was removed. The residual sample was vacuum dried in a centrifuge evaporator Savant SC200 SpeedVac (American Instrument Exchange, Inc., Haverhill, MA, USA) for 6 hours.

\subsection{Scanning electron microscopy (SEM).}

Sample residues were lyophilized and observed using a scanning electron microscope (SEM) (Phillips, mod. XL30). SEM samples were covered with $4 \mathrm{~nm}$ of gold using a sputter coater (Polaron, mod. SC7640).

\subsection{Determination of antioxidant activity.}

The antioxidant activity of extracts was measured by the improved Trolox equivalent antioxidant capacity (TEAC) assay, performed essentially as previously described [16] for carotenoids standards. Briefly, ABTS•+ radical cation was generated by reacting $7 \mathrm{mM}$ ABTS and $2.45 \mathrm{mM}$ potassium persulfate (final concentration) after incubation at room temperature for $16 \mathrm{~h}$ in the dark. The ABTS $\bullet+$ radical solution was diluted with ethanol to give an absorbance of around 0.70 at $734 \mathrm{~nm}$. The reaction was initiated by the addition of $10 \mu \mathrm{l}$ of Haematococcus pluvialis extract (dissolved in its respective solvent) to $0.990 \mathrm{ml}$ of diluted ABTS •+. The reactive mixture was allowed to stand until the reaction reached a steady state, and the absorbance was immediately recorded at $734 \mathrm{~nm}$. Trolox was used as reference standard, and results were expressed as TEAC values (mmol of Trolox/g of extract). These values were obtained from at least three different concentrations of each extract tested in the assay giving a linear response between 20 and $80 \%$ of the blank absorbance. Moreover, all analyses were done in triplicate.

\subsection{Determination of antimicrobial activity.}

The PLE extracts were individually tested against a panel of microorganisms of importance for the food industry, including Staphylococcus aureus ATCC 25923, Escherichia coli ATCC 11775, Candida albicans ATCC 60193 and Aspergillus niger ATCC 16404.

Bacterial strains stock cultures were kept on nutrient agar at $4{ }^{\circ} \mathrm{C}$. Candida albicans was kept on Sabouraud dextrose agar at $4{ }^{\circ} \mathrm{C}$. Aspergillus niger spores were obtained in vitro from monoconidial cultures after incubation $\left(7\right.$ days, $\left.24^{\circ} \mathrm{C}\right)$ on potato dextrose agar, harvested in sterile distilled water containing $0.1 \%$ tween 80 and stored at $4{ }^{\circ} \mathrm{C}$ until used as inoculums. 


\subsection{HPLC-DAD analysis of the extracts.}

The analysis by HPLC were carried out using two different methods: one for the carotenoid analysis and the second one for the most polar compounds.

All the analysis were performed with an HPLC Agilent HP 1100 Series (Agilent, Palo Alto, CA) equipped with a diode array detector and an automatic Agilent 1200 Series injector.

Carotenoid compounds were analysed with a YMC C30 (YMC, Schermbeck, Germany) C30 analytical column ( $5 \mu \mathrm{m}, 250$ x $4.6 \mathrm{~mm}$ I.D.). The mobile phase was a mixture of acetone and water as an isocratic mixture of $84 \%$ acetone and $16 \%$ water for the first 21 min, followed by a 4 min linear gradient to $97 \%$ acetone and $3 \%$ water for the reminder of the $50 \mathrm{~min}$ run. The flow rate was kept at $1 \mathrm{ml} / \mathrm{min}$. Detection was accomplished by using a diode array system at a wavelength of $480 \mathrm{~nm}$ (scan from 190 to $600 \mathrm{~nm}$ ).

Polar compounds were analysed with a Spherisorb (Waters, Mildford, MA, USA) C18 analytical column $(10 \mu \mathrm{m}, 250 \times 4.6 \mathrm{~mm}$ I.D. $)$. The mobile phase was a mixture of solvent $\mathrm{A}$ (water/acetic acid 95:5) and B (acetonitrile 100\%) according to a step gradient lasting for 30 min, starting from $1 \% \mathrm{~B}$, changing to $2 \% \mathrm{~B}$ at $6 \mathrm{~min}$, increasing to $100 \% \mathrm{~B}$ at $20 \mathrm{~min}$ and keeping $100 \% \mathrm{~B}$ constant for the remainder of the 30 min run. The flow rate was kept at 0.9 $\mathrm{ml} / \mathrm{min}$. Detection was accomplished by using a diode array system at a wavelength of 280 nm (scan from 190 to $600 \mathrm{~nm}$ ).

\subsection{Furosine analysis by HPLC-DAD.}

Chromatographic determination of furosine in algae extracts was performed by RPHPLC following the procedure previously reported for furosine determination in honey [17]. Samples (the necessary amount of extract that contains $50 \mathrm{mg}$ of protein) were hydrolyzed with $8 \mathrm{ml}$ of $8 \mathrm{M} \mathrm{HCl}$ at $110{ }^{\circ} \mathrm{C}$ for $23 \mathrm{~h}$ in a screw-capped Pyrex vial with PTFE-faced septa. The hydrolyzate was filtered with a medium-grade paper filter. A $0.5 \mathrm{ml}$ portion of the filtrate was applied to a Sep-Pak C18 cartridge (Millipore) pre-wetted with $5 \mathrm{ml}$ of methanol and 10 $\mathrm{ml}$ of water. Furosine was eluted with $3 \mathrm{ml}$ of $3 \mathrm{M} \mathrm{HCl}$, and $20 \mu \mathrm{l}$ of this volume was injected into the chromatograph.

The liquid chromatograph consisted in a binary pump model 250 (Perkin-Elmer, Waltham, Massachusetts, USA), a manual injector Rheodyne (model 9125,), an oven (Kariba Instruments, Hengoed, UK) to thermostatize the column, an UV (LDC Analytical, FL, USA) detector and an interface model 406 (Beckman, CA, USA). A C8 Alltech furosine-dedicated column (250 x $4.6 \mathrm{~mm}$; Alltech, Laarne, Belgium) and a linear (binary) gradient were used. The mobile phase was a mixture of solvent A $(0.4 \%$ acetic acid in water, v/v) and B $(0.3 \%$ 
$1 \mathrm{KCl}$ in the solvent $\mathrm{A}$ ) according to a linear gradient lasting $32 \mathrm{~min}$, starting with $100 \% \mathrm{~A}$ until 2 minute 12.5 , changing to $50 \% \mathrm{~A}$ at minute 19.5 , maintained until minute 22 , going back to initial 100\% A at minute 24 and keeping it constant for 8 minutes. The flow rate was kept at $1.2 \mathrm{ml} / \mathrm{min}$. Detection was accomplished at a wavelength of $280 \mathrm{~nm}$.

5

\subsection{HPLC-QqQMS analysis.}

Samples were analyzed in a UHPLC Accela equipped with a C18 analytical column (3 $\mu \mathrm{m}, 150$ x $4.6 \mathrm{~mm}$ i.d.) ACE-100A of Advanced Chromatographic Technologies (Aberdeen, UK) and a Diode array detector (DAD). The mobile phase was a mixture of solvent A $(0.1 \%$ acetic acid in water) and B (methanol), according to a lineal gradient lasting $45 \mathrm{~min}$, starting with $5 \% \mathrm{~B}$ until minute 5 , changing to $80 \% \mathrm{~B}$ at minute 35 , increasing to $100 \% \mathrm{~B}$ at minute 38 , keeping it constant for 7 minutes and going back to initial 5\% B conditions at minute 48 . The flow rate was kept at $700 \mu \mathrm{l} / \mathrm{min}$. The effluent of the column was directly introduced in a TSQ/Quantum Acces triple quadrupole (Thermo Fisher Scientific Inc, Whaltham, MA, USA), operating in negative ESI mode. The nebulizer gas pressure was 40 psi, the capillary temperature was $350{ }^{\circ} \mathrm{C}$ and the voltage $3.0 \mathrm{kV}$.

\subsection{GC-MS analysis.}

Volatile compounds were analyzed with an Agilent-6890N GC system with a split/splitless injector coupled to a Agilent-5973N quadrupole mass spectrometer (Agilent, Palo Alto, CA). The system was controlled by means of Agilent MSD Chemstation software. The column used was a $30 \mathrm{~m}$ x $0.25-\mathrm{mm}$ internal diameter fused silica capillary column coated with a $0.25-\mu \mathrm{m}$ layer of SE-54 (HP-5MS, Agilent). The injection was carried out at $250{ }^{\circ} \mathrm{C}$ in split mode (ratio of 1:20). The volume of sample injected was $1 \mu$. Helium was the carrier gas (7 psi). The oven temperature was programmed as follows: $40{ }^{\circ} \mathrm{C}$ as the initial temperature (maintained for $2 \mathrm{~min}$ ) to $150{ }^{\circ} \mathrm{C}$ in $24 \mathrm{~min}$ at $5{ }^{\circ} \mathrm{C} / \mathrm{min}$, and from $150{ }^{\circ} \mathrm{C}$ to a final temperature of $300^{\circ} \mathrm{C}$ at $15^{\circ} \mathrm{C} / \mathrm{min}$.

Extracts were injected at a concentration of $10 \mathrm{mg} / \mathrm{ml}$. All the extracts were filtered with Millipore Millex HV, PVDF $0.45 \mu \mathrm{m}$ filters.

A solvent delay of 4 min was selected before analyzing the compounds reaching de MS. Compounds were tentatively identified by mass spectrometry in SCAN mode using a mass interval ranging from 35 to 450 . Their spectra were compared with those in a mass spectrometry library (Wiley), with data found in the literature and with standards when available. Additionally, to identify compounds more precisely, their linear retention indices 
1 (RIs) were used when possible. Mixture fom n-undecane to n-octacosane (Aldrich, Sigma-

2 Aldrich Chemie, Steinheim, Germany) dissolved in n-hexane were employed for linear RI 3 calculations.

In order to tentatively identify the saccharides present in the samples, the extracts were derivatized following the method described by Troyano and col. [18]. The samples were treated with $0.1 \mathrm{ml}$ of pyridine, $0.1 \mathrm{ml}$ of 1-(trimethylsilyl) imidazole (TMS) and $0.1 \mathrm{ml}$ of trimethyl chlorosilane (TMCS) as derivatizating agents. The samples were dissolved in a ultrasounds bath for $1 \mathrm{~min}$. The derivatization is instantaneous at room temperature. After 3 minutes, $0.1 \mathrm{ml}$ of hexane and $0.2 \mathrm{ml}$ of distilled water were added. $1 \mu \mathrm{l}$ of the organic phase was injected in the GC-MS.

\section{RESULTS AND DISCUSSION}

\subsection{Subcritical Water Extraction.}

The first step towards an efficient extraction of the microalgae is to test the effect of sample pretreatment on the extraction yield; although the sample is subjected to high pressures (1500 psi) and high temperatures (up to $200{ }^{\circ} \mathrm{C}$ ) during the extraction process, low extraction yields are obtained when using the haematococcus pluvialis microalga without any previous treatment; this fact can be explained, as mentioned before, for the formation of red haematocysts when the microalga is cultivated under stress conditions. To enhance yields, several methods have been studied to improve cell wall damage, as already described under section 2.3. From the four methods tested, the best extractions yields were obtained by treating the sample under three freezing-smashing-thawing cycles (procedure 4). Therefore, this method was selected to pretreat the samples before the extraction in the present work. These pretreatment already showed, in a previous work done in our laboratory using ethanol as pressurized solvent, its effectiveness since it allowed the extraction of $2 \%$ astaxanthin, thus improving the results reported so far in the literature [14].

As mentioned, SWE was tested as a green process to obtain antioxidant and antimicrobial compounds from haematococcus pluvialis; since temperature is one of the factors that mostly influence the selectivity of the extraction process using water as a solvent, different temperatures were tested ranging from 50 to $200^{\circ} \mathrm{C}$, while static time (20 min) was kept constant for all extractions. Table 1 shows the extraction temperatures along with the extraction yields achieved. 
As can be seen, an increase in the extraction temperature leads to an increase in extraction yield, expressed as dried weight of extract. This is likely due to an improvement of mass transfer phenomena from the solid phase to the pressurized liquid bringing about and increase of solubility with temperature. This fact has already been shown in previous studies, when working with pressurized liquids and microalgae [19]. To add some more light on this point, scanning electron microscopy was used to study the residues obtained at different temperatures comparing them with the raw material.

\subsection{Scanning electron microscopy (SEM).}

Regarding the effect of sample pretreatment, Figure 1 shows a series of SEM images of Haematococcus pluvialis comparing the best pretreatments at equal extraction conditions (meaning procedures 3 and 4). It can be seen that the cell wall damage suffered under the same extraction conditions $\left(200{ }^{\circ} \mathrm{C}\right)$ is higher when using the freezing-smashing-thawing pretreatment (procedure 4, Figure 1C) rather than the homogenization with the dispersing tool (procedure 3, Figure 1D). This fact might explain the higher extraction yields obtained with pretreatment 4 .

Regarding the effect of extraction temperature, Figure 1 also shows the SEM images of Haematococcus pluvialis before SWE extraction (Figure 1A), the microalgae residue after SWE at $100{ }^{\circ} \mathrm{C}$ (Figure 1B) and the microalgae residue after SWE at $200{ }^{\circ} \mathrm{C}$ (Figure $1 \mathrm{C}$ ), all of them pretreated by freezing-smashing-thawing procedure. Figure 1D shows the microalga residue after SWE at $200{ }^{\circ} \mathrm{C}$, previously homogenized with the dispersing tool. As can be observed from the SEM images, the surface of the particles has been clearly damaged by the extraction process. It is important to point out the important degradation of the algae after extraction at $200{ }^{\circ} \mathrm{C}$, where the cells seem to be melted and totally gathered among them. This can explain the high extraction yields obtained at $200{ }^{\circ} \mathrm{C}$, compared to $100{ }^{\circ} \mathrm{C}$.

\subsection{Antioxidant and antimicrobial activity analysis.}

As can be seen in Table 1, extracts obtained at 100 and $200{ }^{\circ} \mathrm{C}$ showed the best antioxidant activity in terms of TEAC values. However, there is a substantial difference between the values (five times higher at $200{ }^{\circ} \mathrm{C}$ ), suggesting the presence of more antioxidant compounds when temperature is increased to $200{ }^{\circ} \mathrm{C}$. Moreover, as can be seen also in Table 1, four different microbial species, including a gram negative bacteria (Escherichia coli), a gram positive bacteria (Staphylococcus aureus), a yeast (Candida albicans) and a fungus 
1 (Aspergillus niger), were used to screen the potential antimicrobial activity of the 2 haematococcus pluvialis extracts obtained using subcritical water extraction. The antimicrobial activity was quantitatively assessed by the determination of the minimum inhibitory concentration (MIC) and minimal bactericidal and fungicidal concentration (MBC and MFC).

All the extracts showed a very good antimicrobial activity against bacteria and yeast, no mater the temperature used; however, the extracts showed small antifungical activity against Aspergillus niger. The analysis of the antimicrobial activity of the extracts, as a function of extraction temperature, indicated that an increase in the extraction temperature did not produce a significant change in their antimicrobial activity. Therefore, it seems that temperature does not really affect the extraction of antimicrobial compounds from this microalgae. Only for bacteria the use of low temperatures $\left(50\right.$ or $\left.100{ }^{\circ} \mathrm{C}\right)$ could be favourable to improve the extraction of compounds with antimicrobial activity.

The extracts showing the highest antioxidant activity and good antimicrobial properties (i.e., those obtained at 100 and $200{ }^{\circ} \mathrm{C}$ ) were selected for the subsequent chemical characterization of the compounds responsible of these bioactivities, as described below.

\subsection{HPLC-DAD analysis of the extracts.}

As a first step in the characterization, the presence of carotenoids and high polarity compounds was determined in the extracts obtained at 100 and $200^{\circ} \mathrm{C}$ by HPLC-DAD, using the methods described in section 2.7.

Figure 2 shows the chromatograms of the SWE extracts from haematococcus pluvialis obtained at $100{ }^{\circ} \mathrm{C}$ using A) the method developed for carotenoids and B) the method developed for the more polar compounds. Likewise, Figures $2 \mathrm{C}$ and $2 \mathrm{D}$ shows the chromatograms of the SWE extracts obtained at $200{ }^{\circ} \mathrm{C}$.

As can be seen in Figure 2A, no carotenoids were observed in the extract obtained at $100{ }^{\circ} \mathrm{C}$; however, the profile (Figure $2 \mathrm{~B}$ ) obtained using the HPLC method for more polar compounds showed several peaks with a UV spectra typical of phenolics compounds. The chromatogram and UV spectra for the extract obtained at $200{ }^{\circ} \mathrm{C}$ (Figure 2C) showed no carotenoids, but only one very polar peak (2-4 min) with a maximum absorbance wavelength at $330 \mathrm{~nm}$ (Figure 2D). The chromatogram (extract obtained at $200^{\circ} \mathrm{C}$ ) obtained using the method for polar compounds (Figure 2D) showed a very complex profile, with 21 high intensity peaks and UV-vis spectra with maximum absorbance wavelength ranging from 270 to $280 \mathrm{~nm}$, also typical of phenolic compounds. 
According to these results, it seems clear that no carotenoids are present in the SWE of

2 haematococcus pluvialis when using different temperatures, mainly due to the high non-polar nature of the carotenoids. Considering the characterization of the polar compounds made with HPLC-DAD and their UV-vis spectra, it seems reasonable to suggest the presence of simple phenols of medium-high polarity. To identify these kind of compounds and study their presence in the antioxidant extracts form Haematococcus pluvialis, an HPLC method was adapted to identify simple phenols by HPLC-QqQMS using the SWE extract obtained at 200 ${ }^{\circ} \mathrm{C}$.

\subsection{HPLC-QqQMS analysis of SWE extract from Haematococcus pluvialis.}

The presence of simple phenols in the $200{ }^{\circ} \mathrm{C} \mathrm{SWE}$ extract is compatible with the observed UV spectra, as described above, and with simple algae structures and their evolution capacity. This is the reason why the group of phenolic compounds summarized in Table 2 were arbitrarily selected as standards to fix the analytical conditions for HPLC-QqQMS analysis (e.g., ionization conditions, collision energy, etc).

From the HPLC-QqQMS results obtained (elution time, $\mathrm{m} / \mathrm{z}$ ratio of the molecular ion and the first two fragments), and considering the limitation imposed by the low mass accuracy provided by a QqQ analyzer, it was only possible to confirm the presence of galic acid in the Haematococcus pluvialis extract. Thus, although the existence of other phenolic compounds could not be completely discarded, galic acid is a good candidate to explain, at least, part of the antioxidant activity of these extracts, since this compound is a very well known antioxidant [20]. However, these non conclusive results took us to consider some other compounds that could explain the huge antioxidant activity observed in the $200{ }^{\circ} \mathrm{C}$ extract.

\subsection{HPLC-DAD analysis of the extract obtained at $200{ }^{\circ} \mathrm{C}$ : furosine determination.}

Although, as mentioned, part of the antioxidant activity could be explained by the presence of galic acid, a deeper study was carried out to evidence the presence of other type of compounds in the extracts, that could be originated during the extraction process and contribute to the global antioxidant activity.

The presence of compounds formed during the extraction at high temperature could explain partially the colour and typical smell of the extracts obtained at $200{ }^{\circ} \mathrm{C}$. In this sense, the brown colour and roasted smell could indicate two possibilities: the non enzymatic browning due to Maillard reaction between sugars and aminoacids of the sample, or caramelization of the sugars at the extraction temperature. 
Some Maillard reaction products (MRPs) have already been reported to have antioxidant activity [21,22]. In this sense, the detection of any of these MRPs in the extracts could explain their biological activity. Among the possible MRPs, furosine is a well know product from the reaction between a reductive sugar and the aminoacid lysine, and it can be used as a marker of Maillard reaction.

SWE extracts obtained at 100 and $200^{\circ} \mathrm{C}$ were analyzed by HPLC-DAD, according to the method described in section 2.8. Figure 3 shows the chromatograms of these samples together with the chromatogram of furosine standard. As can be observed, although no furosine was detected in the samples, other peaks appeared in the chromatogram meaning that a possible reaction could occur between a reductive sugar and other aminoacids, such as arginine or glycine, which have been reported to be present in the microalga [23]. However, this part of the study was not conclusive since these standards were not available. Therefore, it is not possible to confirm or deny that Maillard reaction has taken place during the subcritical water extraction process.

On the other side, caramelization reactions can take place when sugars or food with high sugar content are heated. Antioxidant activity of some caramelization products has already been reported [24]. Thus, these products could also be responsible of the antioxidant activity of the extracts from haematococcus pluvialis, obtained at high temperatures (mainly $200^{\circ} \mathrm{C}$ ). Products of carbohydrate breakdown, such as (di-D)-fructose anhydrides (DFAs), are pseudodisaccharides made of non volatile compounds mainly, produced during the caramelization reaction, and are considered caramelization markers suitable for food and food additives [25]. GC-MS was used to determine the presence or absence of caramelization reaction products as well as other compounds responsible of the biological activity observed in the SWE extracts.

\subsection{GC-MS analysis of the extracts.}

As mentioned, GC-MS was used to determine possible compounds responsible of the biological activity of the SWE extracts obtained at 100 and $200{ }^{\circ} \mathrm{C}$. To do this, two different GC-MS methods were applied. Namely, in order to identify saccharides that act as caramelization markers (DFAs), samples were derivatized with TMS and analyzed by GC-MS according to the method described in section 2.10 and the results are given in Table 3. On the other hand, direct GC-MS analysis of the volatile fraction of the SWE extracts was also carried out and the results are shown in Table 4. Both tables, 4 and 5, include a tentative identification of the compounds performed on the basis of the comparison of mass spectra and 
1 linear retention indices (RI), the total area of the compounds and their relative contribution to 2 the total composition (\% Normalized areas).

From the results obtained (Tables 4 and 5), several conclusions can be pointed out:

As can be observed in Table 3, the compound DFA9 (previously assigned as $\alpha-\mathrm{D}$ fructofuranoside-1,2':2, ' '- $\beta$-D-fructopyranoside, [25]) was identified in the extract obtained at $200{ }^{\circ} \mathrm{C}$, with a normalized area contribution of $1.3 \%$. This evidences that a caramelization process has taken place during the extraction, suggesting the presence of caramelization products that could contribute to the antioxidant activities of the extracts.

On the other hand, as can be observed in Table 4, vitamin E ( $\alpha$-tocopherol) was detected in the SWE extracts obtained at $200{ }^{\circ} \mathrm{C}$ (elution time of $32.02 \mathrm{~min}$ ) and not in the SWE extracts obtained at $100^{\circ} \mathrm{C}$. Vitamin E is a well known lipophylic antioxidant and SWE has demonstrated its ability to selectively extract different classes of compounds depending on the temperature used, with the more polar extracted at lower temperatures and the less polar compounds extracted at higher temperatures [26,27]. In this work, we have been able to extract vitamin $\mathrm{E}$ at the highest temperature $\left(200{ }^{\circ} \mathrm{C}\right)$ but not at $100{ }^{\circ} \mathrm{C}$. This compound is suggested to be responsible, together with galic acid (and other simple phenolic compounds), of the antioxidant activity of these extracts. In fact, the SWE extract from Haematococcus pluvialis obtained at $200{ }^{\circ} \mathrm{C}$ contains $0.26 \%$ of Vitamin $\mathrm{E}$, which is reported to be a higher dose than the one necessary to reach a scavenging activity of $34.9 \%$ after only $10 \mathrm{~min}$ [28]. Vitamin E is normally destroyed by heat and oxygen, however, it is not degraded in SWE conditions since the extraction is carried out in an ambient free of oxygen. Moreover, the contribution of other compounds such as caramelization and Maillard reaction products on the antioxidant activity of the SWE extracts cannot be ruled out.

Regarding the antimicrobial activity of the SWE extracts from Haematococcus pluvialis obtained at 100 and $200{ }^{\circ} \mathrm{C}$, as can be seen in Table 4, butanoic acid and propanoic acid,2-hidroxy,methyl ester (methyl lactate) were the major compounds present in both samples. Fatty acids have been reported as potential antimicrobial compounds [29]. The lower proportion present in the SWE extract obtained at $200{ }^{\circ} \mathrm{C}$ could also explain the slightly lower antimicrobial activity of this extract compared to the one obtained at $100{ }^{\circ} \mathrm{C}$. Therefore, the antimicrobial activity of the extracts could be correlated with the presence of these short chain fatty acids.

\section{CONCLUSIONS}


In the present work we have demonstrated the usefulness of SWE as a green and fast extraction method to obtain antioxidant and antimicrobial extracts from Haematococcus

3 pluvialis in red growing phase. The extraction yields achieved with this process reaches $30 \%$

4 of dry weight. Extracts obtained at $200{ }^{\circ} \mathrm{C}$ showed the highest yield and antioxidant activity being this activity associated to the presence of vitamin E, simple phenolics (galic acid), caramelization products and possible Maillard reaction products in the sample. Almost no differences in antimicrobial activity were found among the different extracts and it has been correlated to short chain fatty acids content. Thus, the results presented in this study show the great possibilities of combining green extraction processes, mainly based on SWE, with analytical techniques to obtain and characterize functional ingredients from microalga.

\section{ACKNOWLEDGEMENTS}

This work has been financed by Spanish Ministry of Education (AGL2005-06726-C0401/02/04), Comunidad Autónoma de Madrid (S-0505/AGR/000153) and Consolider Ingenio 2010 FUN-C-FOOD (CSD2007-0063) projects. I.R thanks Dr. Dolores del Castillo and her group for the collaboration in furosine determination and the Comunidad Autónoma de Madrid for her grant.

1. F. Guarner, Azpiroz, F., La evaluación científica de los alimentos funcionales. En: Alimentos Funcionales. Juárez, M., Olano, A., Morais, F. Publicaciones FECYT, Madrid, 2005, p.12.

2. M. Plaza, Cifuentes, A., Ibáñez, E., Trends in Food Science \& Technology, 19 (2008) 31-39.

3. M.J. Carlucci, Scolaro, L.A., Damonte, E.B., Chemotherapy, 45 (1999) 429-436.

4. J.-P. Yuan, Chen, F., Journal of Agricultural and Food Chemistry, 46 (1998) 33713375.

5. M.A. Borowitzka, Pharmaceuticals and agrochemicals from microalgae, in Chemicals from microalgae, Z. Cohen, Editor. Taylor \& Francis, London, UK., 1999, p. 313-352.

6. R.L. Mendes, B.P. Nobre, M.T. Cardoso, A.P. Pereira, and A.F. Palavra, Inorganica Chimica Acta, 356 (2003) 328-334.

7. Z. Cohen, Chemicals from microalgae. 1999, London: Taylor \& Francis.

8. E. Molina Grima, E.H. Belarbi, F.G. Acién Fernández, A. Robles Medina, and Y. Chisti, Biotechnology Advances, 20 (2003) 491-515.

9. M. Orosa, Franqueira, D., Cid, A., Abalde, J., Bioresource Technology, 96 (2005) 373-378.

10. -Bocanegra, Guerrero Legarreta, I., Martinez Jeronimo, F., Tomasini Campocosio, A., Bioresource Technology, 92 (2004) 209-214. 
11. J.R. Denery, K. Dragull, Tang,C.S. and Li, Q.X., Analytica Chimica Acta, 501 (2004) 175-181.

12. E.M.Z. Michielin, L.F.V. Bresciani, L. Danielski, R.A. Yunes, and S.R.S. Ferreira, Journal of Supercritical Fluids, 33 (2005) 131-138.

13. T.R. Sommer, Potts, W.T., Morrissy, N.M., Aquaculture, 94 (1990) 79-88.

14. R. Sarada, Vidhyavathi, R., Usha, D., Ravishankar, G.A., Journal of Agricultural and Food Chemistry, 54 (2006) 7585-7588.

15. M.I. Mínguez-Mosquera, Clorofilas y carotenoides en tecnología de alimentos. Secretariado de publicaciones. 1997, Universidad de Sevilla. pp. 111-152.

16. R.P. Re, N.; Proteggente, A.; Pannala, A.; Yang, M.; Rice-Evans, C., Free Radical Biology and Medicine, 26 (1999) 1231-1237.

17. M. Villamiel, M.D.del Castillo, N. Corzo, A. Olano, Journal of the Science of Food and Agriculture, 81 (2001) 790-793.

18. E. Troyano, A. Olano, M. Frenández-Díaz, J. Sanz, I. Martínez-Castro, Chromatographia, 32 (1991) 379-382.

19. M. Herrero, P.J. Martin-Alvarez, F.J. Senorans, A. Cifuentes, and E. Ibanez, Food Chemistry, 93 (2005) 417-423.

20. C. Sgherri, Cosi, E., Navari-Izzo, F., Physiologia Plantarum, 118 (2003) 21-28.

$21 . \quad$ - , T., Journal of Agricultural and Food Chemistry, 49 (2001) 5031-5038.

22. K. Yanagimoto, Lee, K.G., Ochi, H., Shibamoto, T., Journal of Agricultural and Food Chemistry, 50 (2002) 5480-5484.

23. A Technical Review of Haematococcus Algae, http://www.cyanotech.com/pdfs/bioastin/axbul60.pdf., last access 2009-01-09.

24. S. Benjakul, Visessanguan, W., Phongkanpai, V., Tanaka, M., Food Chemistry, 90 (2005) 231-239.

25. A. Montilla, A.I. Ruiz-Matute, M.L. Sanz, I. -Castro, M.D. del Castillo, Food Research International, 39 (2006) 801-806.

26. I. Rodriguez-Meizoso, F.R. Marin, M. Herrero, F.J. Senorans, G. Reglero, A. Cifuentes, and E. Ibanez, Journal of Pharmaceutical and Biomedical Analysis, 41 (2006) 1560-1565.

27. E. Ibañez, A. Kubátová, F.J. Señoráns, S. Cavero, G. Reglero, and S.B. Hawthorne, Journal of Agricultural and Food Chemistry, 51 (2003) 375-382.

28. D. Liu, Shi, J., Colina Ibarra, A., Kakuda, Y., Jun Xue, S., LWT - Food Science and Technology, 41 (2008) 1344-1349.

29. K. Benkendorff, A.R. Davis, C.N. Rogers, and J.B. Bremner, Journal of Experimental Marine Biology and Ecology, 316 (2005) 29-44. 


\section{$1 \quad$ Figure Legends}

2 Figure 1. SEM pictures of the haematococcus pluvialis A) before the extraction process, B)

3 residue after $\mathrm{SWE}$ at $100{ }^{\circ} \mathrm{C}$ using the freezing-smashing-thawing pretreatment, $\mathrm{C}$ ) residue

4 after SWE at $200{ }^{\circ} \mathrm{C}$ using the freezing-smashing-thawing pretreatment and D) residue after

$5 \quad$ SWE at $200^{\circ} \mathrm{C}$ using the dispersing tool pretreatment.

6 Figure 2. Chromatograms of the SWE extract from Haematococcus pluvialis obtained at 100

$7 \quad{ }^{\circ} \mathrm{C}$ using the HPLC method for the analysis of A) carotenoids and B) polar compounds.

8 Chromatograms of the SWE extract from Haematococcus pluvialis obtained at $200{ }^{\circ} \mathrm{C}$ using

9 the HPLC method for the analysis of C) carotenoids and D) polar compounds.

10 Figure 3. Chromatograms of the furosine standard and extracts obtained at 100 and $200{ }^{\circ} \mathrm{C}$. 
1 Table 1. Extraction yields obtained (\% dry weight), antimicrobial and antioxidant activities of

2 SWE extracts from Haematococcus pluvialis obtained at different temperatures.

\begin{tabular}{|c|c|c|c|c|c|c|}
\hline $\begin{array}{l}\text { SWE } \\
\text { extracts }\end{array}$ & Yield (\%) & $\begin{array}{c}\text { Escherichia } \\
\text { coli } \\
\mathrm{MBC}^{1} \\
(\mathrm{mg} / \mathrm{ml})\end{array}$ & $\begin{array}{c}\text { Staphylococcus } \\
\text { aureus } \\
\\
\mathrm{MBC} \\
(\mathrm{mg} / \mathrm{ml})\end{array}$ & $\begin{array}{c}\text { Candida } \\
\text { albicans } \\
\\
\mathrm{MFC}^{2} \\
(\mathrm{mg} / \mathrm{ml})\end{array}$ & $\begin{array}{c}\text { Aspergillus } \\
\text { niger } \\
\\
\text { MFC } \\
(\mathrm{mg} / \mathrm{ml})\end{array}$ & $\begin{array}{c}\text { Antioxidant } \\
\text { Activity } \\
\text { TEAC }\end{array}$ \\
\hline $50^{\circ} \mathrm{C}$ & 20 & 3.0 & 4.0 & 6.5 & 16 & $0.388 \pm 0.012$ \\
\hline $100^{\circ} \mathrm{C}$ & 21 & 3.0 & 4.0 & 5.5 & 15 & $0.453 \pm 0.004$ \\
\hline $150^{\circ} \mathrm{C}$ & 32 & 5.0 & 5.0 & 5.5 & 15 & $0.366 \pm 0.012$ \\
\hline $200^{\circ} \mathrm{C}$ & 33 & 5.0 & 5.0 & 5.5 & 15 & $1.974 \pm 0.053$ \\
\hline $\begin{array}{l}\text { Reference } \\
\text { Antibiotic }\end{array}$ & & 0.01 & 0.01 & 0.10 & 0.15 & \\
\hline
\end{tabular}

$3 \frac{}{1} \mathrm{MBC}$, minimum bactericidal concentration. ${ }^{2} \mathrm{MFC}$, minimum fungicidal concentration. 
1 Table 2. Phenolic compounds used as standards for the HPLC-QqQMS analysis of the SWE

2 extract from Haematococcus pluvialis obtained at $200{ }^{\circ} \mathrm{C}$.

\begin{tabular}{|c|c|c|c|}
\hline Identified Compound & $\mathrm{m} /{\mathrm{z} \mathrm{M}-\mathrm{H}^{-} \text {(fragments) }}^{\text {Collision energy }}$ & Tube lens \\
\hline Carvacrol & $150.1(135.2)$ & 14 & 82 \\
\hline p-hydroxybenzoic acid & $137.1(108.3 ; 93.4)$ & $28 ; 18$ & 66 \\
\hline Galic acid & $169.1(125.3 ; 124.3)$ & $16 ; 26$ & $82 ; 63$ \\
\hline Siringic acid & $196.9(182.2 ; 123.2)$ & $18 ; 25$ & 55 \\
\hline Vanillic acid & $167.1(152.2 ; 108.3)$ & $15 ; 19$ & 62 \\
\hline Protocachuic acid & $153.1(109.3 ; 108.3)$ & $19 ; 26$ & 58 \\
\hline Sinapic acid & $223.1(208.1 ; 164.2)$ & $14 ; 19$ & 61 \\
\hline Ferulic acid & $193.1(178.2 ; 134.3)$ & $13 ; 20$ & 60 \\
\hline Caffeic acid & $179.1(135.3 ; 134.3)$ & $18 ; 26$ & $63 ; 56$ \\
\hline Chlorogenic acid & $353.1(191.1 ; 85.4)$ & $21 ; 47$ & 62 \\
\hline
\end{tabular}

3

4 
1 Table 3. GC-MS of the SWE extract obtained at $200{ }^{\circ} \mathrm{C}$ derivatized with TMS.

\begin{tabular}{|c|c|c|c|}
\hline $\begin{array}{l}\text { Retention } \\
\text { time/min }\end{array}$ & Identification & Areas & $\begin{array}{c}\% \\
\text { Normalized } \\
\text { areas }\end{array}$ \\
\hline 4.73 & Silane,trimethyl(2-methylpropoxy) & 333000 & 4.8 \\
\hline 5.56 & NI & 82000 & 1.2 \\
\hline 8.31 & Methylbis(trimethylsilyloxy)silane & 73000 & 1.1 \\
\hline 10.55 & Silanamine,N,N'-methanetetraylbis[1,1,1-trimethyl- & 278000 & 4.0 \\
\hline 11.26 & 3,6-Dioxa-2,7disilaoctane-2,2,7,7-tetramethyl & 16000 & 0.2 \\
\hline 11.79 & 3,6-Dioxa-2,7disilaoctane-2,2,7,7-pentamethyl & 12000 & 0.2 \\
\hline 11.94 & Heptane,3-(chloromethyl)- & 14000 & 0.2 \\
\hline 12.83 & 2,3-butanediol 2TMS PK B & 17000 & 0.2 \\
\hline 13.1 & 2,3-butanediol 2TMS PK B & 13000 & 0.2 \\
\hline 13.49 & 1,3-propandiol,bis-(trimethylsilyl)- & 20000 & 0.3 \\
\hline 14.92 & Silane,[(2-ethylhexyl)oxy)trimethyl- & 45000 & 0.6 \\
\hline 15.2 & Silanamine,1,1,1-trimethyl-N,N-bis(trimethylsilyl)- & 148000 & 2.1 \\
\hline 19.06 & $\begin{array}{l}\text { 3,6,9-Trioxa-2,10-disilaundecane,2,2,10,10- } \\
\text { tetramethyl }\end{array}$ & 15000 & 0.2 \\
\hline 20.06 & $\begin{array}{c}\text { 3,7-dioxa-2,8-disilanonane,2,2,8,8-tetramethyl-5- } \\
\text { [(trimethylsilyl)oxy]- }\end{array}$ & 479000 & 6.9 \\
\hline 25.69 & $\begin{array}{c}\text { 3,8-dioxa-2,9-disiladecane,2,2,9,9-tetramethyl-5,6- } \\
\text { bis[(trimethylsilyl)oxy]-/// ///Threitol,1,2,3,4-tetrakis- } \\
\text { O-(trimethylsilyl)-,D- }\end{array}$ & 22000 & 0.3 \\
\hline 25.83 & $\begin{array}{c}\text { 3,8-dioxa-2,9-disiladecane,2,2,9,9-tetramethyl-5,6- } \\
\text { bis[(trimethylsilyl)oxy]-/// Threitol,1,2,3,4-tetrakis- } \\
\text { O-(trimethylsilyl)-,D- }\end{array}$ & 47000 & 0.7 \\
\hline 26.48 & NI & 26000 & 0.4 \\
\hline 27.07 & TMS derivative of authentic 2-deoxyribitol & 18000 & 0.3 \\
\hline 27.97 & DFA9 & 88000 & 1.3 \\
\hline 28.19 & Xylitol 5TMS /// Arabitol 5TMS & 46000 & 0.7 \\
\hline 28.26 & $\begin{array}{l}\text { 1H-Indole-2-carboxylic acid, 1-methyl, trimethylsilyl } \\
\text { ester }\end{array}$ & 14000 & 0.2 \\
\hline 28.29 & D-Galactose,2,3,4,,5,6-pentakis-O-trimethylsilyl & 16000 & 0.2 \\
\hline 28.33 & $\begin{array}{c}\text { Glucopyranose,4,6-di-O-methyl-1,2,3-tris-O- } \\
\text { (trimethylsilyl)- }\end{array}$ & 18000 & 0.3 \\
\hline 28.41 & Arabitol 5TMS & 17000 & 0.2 \\
\hline 28.46 & Ribitol-1,2,3,4,5-pentatms & 18000 & 0.3 \\
\hline 28.51 & $\begin{array}{c}\text { Beta-D-Glucopyranose,6-O-methyl-1,2,3,4-tetrakis- } \\
\text { O-(trimethylsilyl)- }\end{array}$ & 12000 & 0.2 \\
\hline 28.81 & NI & 257000 & 3.7 \\
\hline 28.95 & NI & 43000 & 0.6 \\
\hline 29.18 & NI & 425000 & 6.1 \\
\hline 29.23 & D-Fructose, 1,2,3,4,5-pentakis-O-(trimethylsilyl)- & 118000 & 1.7 \\
\hline 29.31 & Sorbose 5TMS & 272000 & 3.9 \\
\hline 29.45 & NI & 50000 & 0.7 \\
\hline 29.60 & NI & 50000 & 0.7 \\
\hline 29.85 & $\begin{array}{c}\text { Alpha-D-mannopyranose, } 1,2,3,4,6 \text {-pentakis-O- } \\
\text { trimethylsilyl)- }\end{array}$ & 161000 & 2.3 \\
\hline
\end{tabular}




\begin{tabular}{|c|c|c|c|}
\hline 29.97 & D-Glucose,2,3,4,5,6-pentakis-O-(trimethylsilyl)- & 250000 & 3.6 \\
\hline 30.19 & D-Sorbitol,hexakis-O-(trimethylsilyl)- & 280000 & 4.0 \\
\hline 30.47 & Mannose,2,3,4,5,6-pentakis-O-(trimethylsilyl)-,D- & 235000 & 3.4 \\
\hline 30.74 & Hexadecanoic acid TMS ester & 29000 & 0.4 \\
\hline 31.27 & Inositol,1,2,3,4,5,6-hexakis-O-(trimethylsilyl)-,cis- & 320000 & 4.6 \\
\hline 32.58 & NI & 15000 & 0.2 \\
\hline 32.87 & Hexanedioic acid,dioctyl ester & 168000 & 2.4 \\
\hline 33.31 & NI & 39000 & 0.6 \\
\hline 33.72 & 1,2-Bencenedicarboxylic acid,bis(2-ethylhexyl) ester & 2031000 & 29.3 \\
\hline 34.42 & NI & 30000 & 0.4 \\
\hline 34.69 & Maltose octaTMS & 180000 & 2.6 \\
\hline 34.84 & Maltose octaTMS & 79000 & 1.1 \\
\hline
\end{tabular}

1 NI: non identified 
1 Table 4. GC-MS of the SWE extracts obtained at 100 and $200{ }^{\circ} \mathrm{C}$.

\begin{tabular}{|c|c|c|c|c|c|c|}
\hline \multirow[b]{2}{*}{$\begin{array}{l}\text { Retention } \\
\text { Time/min }\end{array}$} & \multirow[b]{2}{*}{ Identification } & \multirow[b]{2}{*}{ RI } & \multicolumn{2}{|c|}{ Extract at $100^{\circ} \mathrm{C}$} & \multicolumn{2}{|c|}{ Extract at $200^{\circ} \mathrm{C}$} \\
\hline & & & Areas & $\begin{array}{l}\text { Normalized } \\
\text { areas }\end{array}$ & Areas & $\begin{array}{l}\text { Normalized } \\
\text { areas }\end{array}$ \\
\hline 5.38 & Butanoic acid & 812 & 35000 & 6.8 & 50000 & 4.5 \\
\hline 8.10 & $\begin{array}{c}\text { Propanoic acid,2- } \\
\text { hidroxy,methyl ester (methyl } \\
\text { lactate) }\end{array}$ & 909 & 445000 & 86.6 & 489000 & 44.2 \\
\hline 11.78 & $\begin{array}{l}\text { 2-Cyclopenten-1-one,2- } \\
\text { hydroxy-3-methyl }\end{array}$ & 1028 & & - & 21000 & 1.9 \\
\hline 12.19 & Benzeneacetaldehyde & 1042 & 2000 & 0.4 & 3000 & 0.2 \\
\hline 12.74 & Isobarbituric acid? & 1059 & & - & 14000 & 1.3 \\
\hline 13.28 & 2-Pyrrolidinone & 1077 & & - & 40000 & 3.6 \\
\hline 15.24 & $\begin{array}{c}\text { 4H-Pyran-4-one,2,3-dihydro- } \\
\text { 3,5-dighydroxy-6-methyl }\end{array}$ & 1142 & 15000 & 2.9 & 9000 & 0.8 \\
\hline 15.61 & $\begin{array}{l}\text { N,N-Dimethylhomoserine } \\
\text { lactone }\end{array}$ & 1155 & & - & 5000 & 0.5 \\
\hline 16.67 & NI & 1191 & & - & 46000 & 4.2 \\
\hline 20.03 & Cyclotrisiloxane,octamethyl & 1311 & 10000 & 1.9 & & - \\
\hline 26.82 & $\begin{array}{l}\text { 3,4,5,6-Tetrahydro-1,3- } \\
\text { dimethyl-2(1H)- } \\
\text { pyrimidinone }\end{array}$ & 1642 & & - & 21000 & 1.9 \\
\hline 27.66 & NI & 1722 & & - & 33000 & 2.9 \\
\hline 27.82 & NI & 1737 & & - & 41000 & 3.7 \\
\hline 28.13 & NI & 1767 & & - & 24000 & 2.2 \\
\hline 28.18 & NI & 1771 & & - & 19000 & 1.7 \\
\hline 28.68 & NI & 1826 & & - & 21000 & 1.9 \\
\hline 28.89 & NI & 1852 & & - & 36000 & 3.3 \\
\hline 29.20 & NI & 1892 & & - & 6000 & 0.6 \\
\hline 29.49 & NI & 1929 & & - & 15000 & 1.4 \\
\hline 29.58 & $\mathrm{NI}$ & 1940 & & - & 9000 & 0.9 \\
\hline 29.61 & NI & 1944 & & - & 50000 & 4.5 \\
\hline 29.69 & NI & 1954 & & - & 27000 & 2.4 \\
\hline 29.72 & NI & 1958 & & - & 49000 & 4.4 \\
\hline 29.75 & Hexadecanoic acid & 1962 & 7000 & 1.4 & & - \\
\hline 32.02 & Vitamin E & 2313 & & & 79000 & 7.2 \\
\hline
\end{tabular}



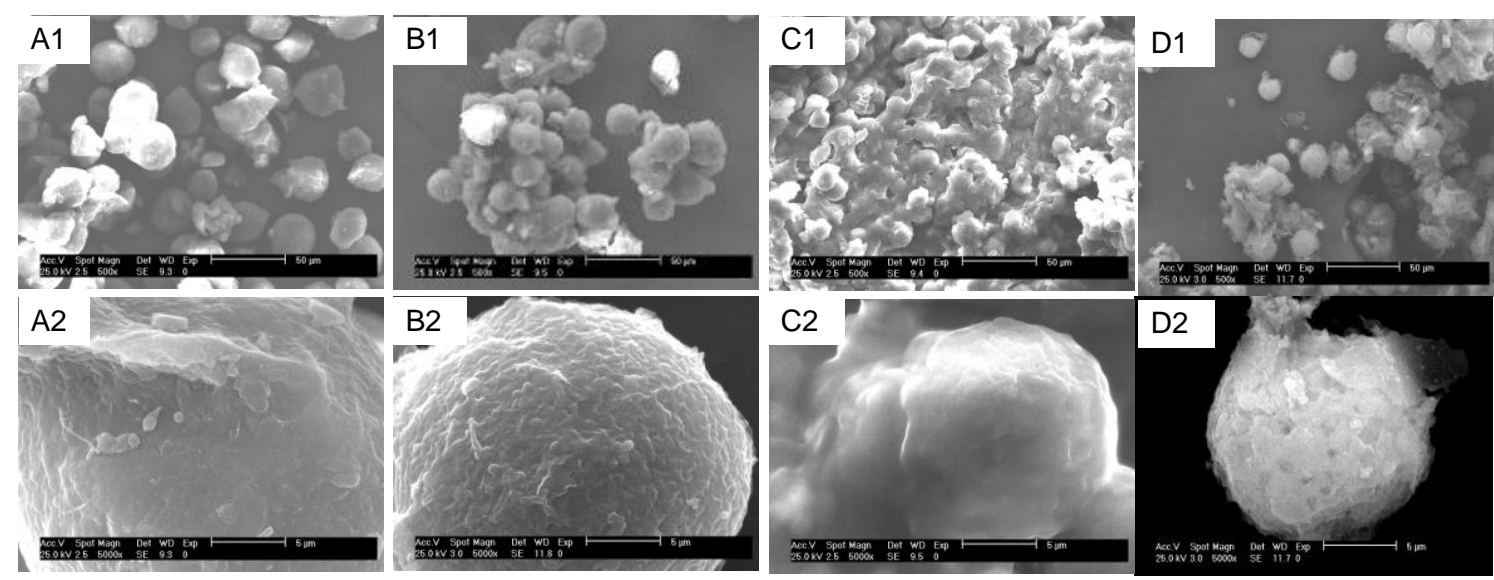

2 Figure 1.

3 


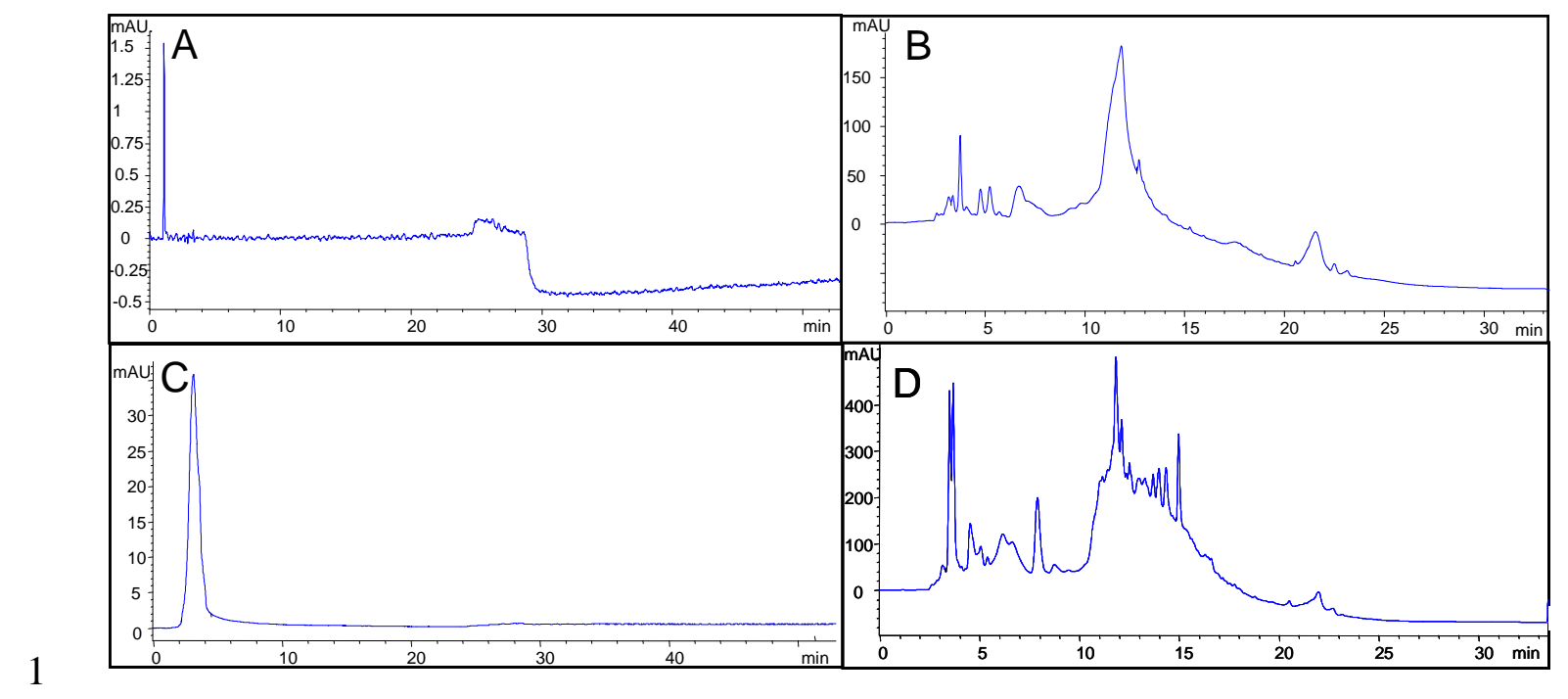

2 Figure 2. 


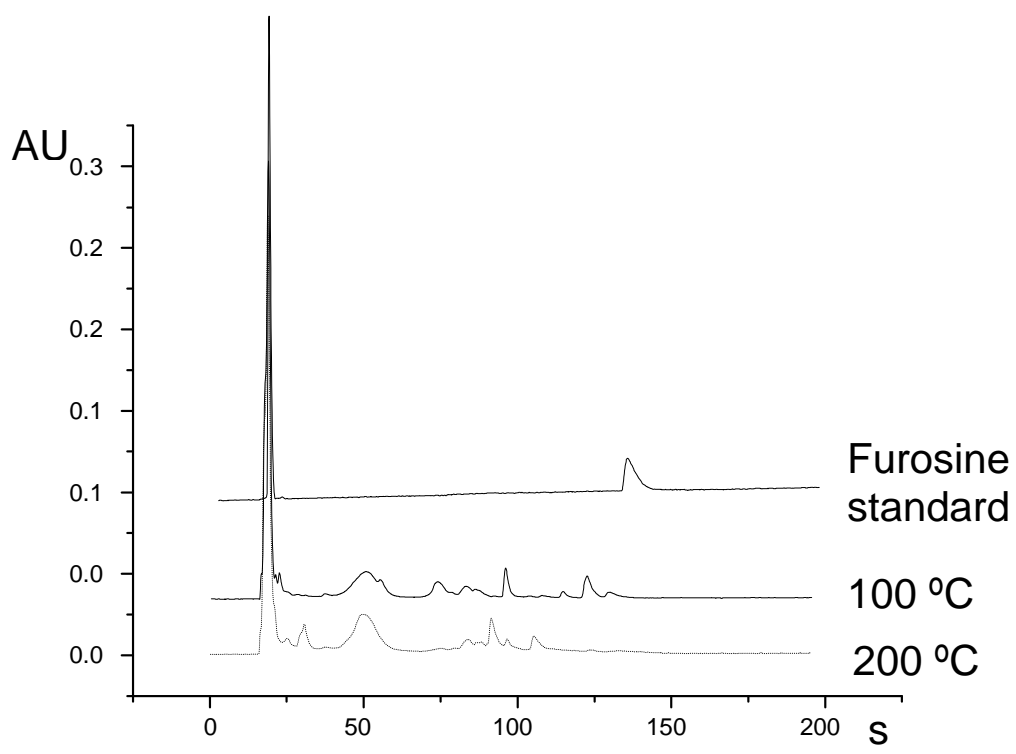

2 Figure 3.

3 